\title{
Korelasi Nilai CD4 dengan Left Ventricular Mass Index pada Anak dengan Infeksi Human Immunodeficiency Virus
}

Rizki Ayu Rizal, Sri Endah Rahayuningsih, Anggraini Alam

Bagian Ilmu Kesehatan Anak RSUP Hasan Sadikin, Fakultas Kedokteran Universitas Padjajaran, Bandung

Latar belakang. Infeksi Human Immunodeficiency Virus (HIV) merupakan masalah kesehatan anak di beberapa negara. Pemeriksaan kadar CD4 adalah parameter terbaik untuk mengukur imunodefisiensi. Jantung sebagai salah satu organ yang dapat menjadi sumber morbiditas dan mortalitas pada pasien HIV belum menjadi perhatian khusus.

Tujuan. Untuk mengetahui korelasi nilai CD4 dengan left ventricular mass index pada anak dengan infeksi HIV.

Metode. Penelitian ini menggunakan rancangan potong lintang di klinik Rumah Sakit Umum Pusat Dr. Hasan Sadikin bulan Januari 2020. Populasi penelitian ini adalah anak terdiagnosis HIV berusia $>5-<18$ tahun yang memenuhi kriteria inklusi. Analisis korelasi antara CD4 dan LVMI dilakukan dengan menggunakan uji korelasi Spearman.

Hasil. Kami melakukan pemeriksaan ekokardiografi pada 62 anak, dua anak memenuhi kriteria eksklusi berupa penyakit jantung bawaan, dan kelainan katup. Nilai CD4 absolut adalah $822 \pm 380 \mathrm{sel} / \mathrm{mm}^{3}$. Korelasi negatif terjadi antara nilai CD4 dengan LVMI, tetapi tidak signifikan $(\mathrm{r}=-0,050, \mathrm{p}=0,377)$.

Kesimpulan. Abnormalitas kardiovaskular dapat terjadi pada anak HIV. Pada penelitian ini, nilai CD4 tidak berhubungan dengan peningkatan LVMI pada anak HIV, tetapi pemeriksaan ekokardiografi merupakan teknik yang berguna untuk mendeteksi abnormalitas kardiovaskular pada anak HIV. Sari Pediatri 2020;22(1):37-42

Kata kunci: CD4, left ventricular mass index, HIV, anak

\section{Correlation of CD4 with Left Ventricular Mass Index in Human Immunodeficiency Virus Children}

Rizki Ayu Rizal, Sri Endah Rahayuningsih, Anggraini Alam

Background. Human immunodeficiency virus (HIV) infection has become an important health problem in children in many countries. The best parameter to measure immunodeficiency is CD4. Heart is one of the organs that can be a source of morbidity and mortality HIV children, yet still not gained adequate concern.

Objective. To determine the correlation of CD4 cell counts with left ventricular mass index in HIV children.

Methods. This cross-sectional study was conducted to HIV-infected children who routinely visit at HIV clinic General Hospital Dr. Hasan Sadikin Bandung in January 2020. Comparative analysis between CD4 and LVMI was performed using the Spearman test.

Result. We performed echocardiography in $62 \mathrm{HIV}$-infected children. Two subjects were excluded due to their acquired congenital heart defects and valve abnormality. Mean absolute CD4 cell count was $822 \pm 380$ cells $/ \mathrm{mm}^{3}$. There is negative correlation between CD4 and LVMI even though no significant ( $r=-0.050, \mathrm{p}=0.377)$.

Conclusion. Cardiovascular abnormalities can occur in HIV children infection although they do not show clinical manifestations. In this study, CD4 was not associated with an increased LVMI in HIV children, despite echocardiography can be a useful technique for detecting cardiovascular abnormalities in HIV children. Sari Pediatri 2020;22(1):37-42

Keywords: CD4, Left ventricular mass index, left ventricular mass, HIV, children

Alamat korespondensi: Endah Rahayuningsih Departemen Ilmu Kesehatan Anak Fakultas Kedokteran UNPAD/Rumah Sakit Hasan Sadikin, Jalan Pasteur No.38 Bandung 40161.Email: seraning@yahoo.com 
I nfeksi human immunodeficiency virus (HIV) merupakn masalah kesehatan pada anak di banyak negara. Human immunodeficiency virus merupakan retrovirus pada subfamili Lentivirinae. Jantung merupakan organ yang menjadi sumber morbiditas dan mortalitas pada pasien HIV, tetapi belum menjadi perhatian khusus. Masalah jantung dapat dikaitkan dengan adanya nilai CD4 rendah. ${ }^{1}$ Human Immunodeficiency Virus menginfeksi limfosit $\mathrm{T}$ cluster of differentiation 4 (CD4), akibat diserangnya limfosit CD4 menyebabkan defisiensi sistem imun. Perubahan jumlah CD4 menjadi indikator respon seseorang terhadap antiretroviral (ARV). Nilai CD4 merupakan parameter terbaik untuk mengukur imunodefisiensi digunakan bersamaan dengan penilaian klinis serta sebagai petunjuk dini progresivitas penyakit karena nilai CD4 menurun lebih dahulu dibandingkan kondisi klinis. $2, \underline{3}$

Pada tahun 2018, di Indonesia terdapat 327.282 kasus infeksi HIV. Jawa barat merupakan provinsi ketiga dengan jumlah infeksi HIV terbanyak di Indonesia. Menurut laporan dari sistem informasi buman immunodeficiency virus / acquired immune deficiency syndrome dan infeksi menular seksual (SIHA) di Indonesia, pada tahun 2018 infeksi HIV terjadi 988 $(2,1 \%)$ kasus pada anak $\leq 4$ tahun, $459(1,0 \%)$ anak 5-14 tahun, 1434 (3,1\%) anak 15-19 tahun. ${ }^{4}$

Infeksi HIV melibatkan setiap sistem, termasuk hematologi, sistem saraf pusat, sistem pernapasan dan kardiovaskular. Hubungan antara HIV dengan kardiovaskular merupakan hubungan kompleks dan multifaktorial akibat aktivasi sistem imun ataupun adanya inflamasi kronik. Jantung termasuk organ yang dapat menjadi sumber morbiditas dan mortalitas pada pasien HIV.

Pengukuran dengan ekokardiografi dapat mengukur left ventricular mass (LVM) yang menentukan adanya hipertrofi ventrikel kiri, parameter ini dilakukan untuk memprediksikan luaran dan risiko kardiovaskular dalam kondisi tertentu. Indeks pengukuran LVM berdasarkan tinggi badan atau dengan luas permukaan tubuh digunakan sebagai perbandingan antara individu dengan berbagai ukuran tubuh. Left ventricular hipertropy dikenal sebagai faktor risiko independen dalam menilai morbiditas dan mortalitas kardiovaskular pada dewasa. Pada populasi anak, LVH terjadi pada kondisi kelainan jantung bawaan dan kardiomiopati. Left ventricular hipertropy didefinisikan dengan left ventricular mass index (LVMI) lebih dari persentil ke-95 menggunakan interval referensi spesifik usia untuk anak-anak normal. ${ }^{5}$

Human immunodeficiency virus dapat menginfeksi miosit jantung. Penyebab pasti manifestasi kardiologi pada anak HIV belum dapat di dijelaskan secara pasti, tetapi kemungkinan besar karena berbagai penyebab, yaitu depresi sistem imun, infeksi oportunistik, penggunaan obat-obatan dan beberapa faktor lain. Abnormalitas jantung menjadi penyebab kematian langsung pada kasus HIV. Laporan di India menemukan $11,8 \%$ kasus HIV yang mengalami abnormalitas jantung dengan insiden meningkat 25\% pada anak usia di atas 10 tahun. ${ }^{6}$ Penelitian di Afrika tentang disfungsi diastolik dan hipertrofi ventrikel kiri pada anak HIV mendapatkan hasil peningkatan LVM dan disfungsi diastolik yang sangat jelas pada pasien HIV dibandingkan dengan kelompok kontrol. ${ }^{7}$ Saat ini masih sedikit penelitian yang melaporkan insidensi keterlibatan kardiovaskular pada anak, terutama di Indonesia.

\section{Metode}

Penelitian ini menggunakan desain potong lintang, pada pasien HIV anak yang berobat ke klinik Teratai Rumah Sakit Umum Pusat (RSUP) Dr. Hasan Sadikin Bandung pada bulan Januari 2020 setelah mendapat izin dari Komite Etik Penelitian Rumah Sakit Umum Pusat Dr Hasan Sadikin Bandung. Kriteria inklusi yaitu: anak berusia $>5$ tahun $-\leq 18$ tahun yang telah terdiagnosis HIV dan bersedia mengikuti penelitian dan menandatangani surat persetujuan. Kriteria ekslusi, yaitu 1) riwayat penyakit jantung bawaan dan kelainan katup sebelum terdiagnosis HIV atau 2) aritmia berdasarkan pemeriksaan elektrokardiografi (EKG).

Informed consent dilakukan terhadap orangtua subjek yang memenuhi kriteria penelitian. Dilakukan pengumpulan data penelitian yang terdiri dari jenis kelamin, usia, lama terapi, status gizi, jenis obat ARV, nilai CD4, dan dimensi jantung berupa LVMI. Status gizi ditentukan dengan kurva indeks massa tubuh menurut usia dari World Health Organization (WHO). Pengumpulan sampel darah sebanyak 4 mililiter pada tabung EDTA untuk pemeriksaan CD4 menggunakan metode flow cytometry. Pemeriksaan ekokardiografi seluruh subjek penelitian yang memenuhi kriteria inklusi dilakukan oleh konsultan kardiologi anak dalam 
keadaan tenang dan posisi berbaring. Pemeriksaan dilakukan menggunakan alat ekokardiografi Philips Epic 5C. Pasien dilakukan pemeriksaan dua dimensi, $M$-mode dan $M$-mode dengan Doppler berwarna. Pengukuran dilakukan sebanyak tiga kali dan diambil nilai rata-rata. Data ekokardiografi yang dikumpulkan berupa intraventricular septal end diastole (IVSd), Left ventricular end diastolic diameter (LVEDD), Posterior wall thicknes at end diastole (PWd), LV mass, LVMI (Left ventricular mass index).,, 2

Pengukuran LVM dihitung dengan menggunakan formula: LVM $(\mathrm{g})=0,8(1,04((\mathrm{LVEDD}+\mathrm{IVSd}+$ PWd ${ }^{3}$ LVEDD $\left.\left.^{3}\right)\right)$ ).

Kriteria LVH yaitu nilai left ventricular mass index (LVMI) $\geq$ persentil 95 untuk anak dan remaja normal. Sebelum dilakukan analisis bivariabel dilakukan uji normalitas data dengan menggunakan uji normalitas Kolmogorov Smirnov untuk besar sampel lebih dari 50 orang. Analisa korelasi antara CD4 dan LVMI dilakukan dengan menggunakan uji korelasi Spearman. Interpretasi hasil uji hipotesis ditetapkan berdasarkan kekuatan korelasi, arah korelasi, dan nilai p. Analisis data dilakukan dengan menggunakan program Statistical Product and Service Solution (SPSS) for Windows versi 20.0.

\section{Hasil}

Selama periode penelitian di RSUP Hasan Sadikin
Tabel 1. Karakteristik penelitian

\begin{tabular}{lc}
\hline Karakteristik & Nilai \\
\hline Jenis kelamin, n (\%) & \\
Laki-laki & $28(53,2)$ \\
Perempuan & $10,8 \pm 3,5$ \\
Usia saat ini (tahun), rerata & \\
rerata \pm SD & $2,5(0,3-8,0)$ \\
Usia mulai terdiagnosis (tahun) & \\
rerata \pm SD & $7,5 \pm 3,5$ \\
Lama terapi antiretrovirus (tahun) & \\
Status gizi, n(\%) & $41(68,3)$ \\
Normal & $8(13,3)$ \\
Wasted & $7(11,7)$ \\
Severe wasted & $3(5,0)$ \\
Overweight & $1(1,7)$ \\
Obesitas & $25(41 \%)$ \\
Left ventricular hipertrofi, n(\%) & \\
Terapi, n(\%) & $4(6,7)$ \\
Tenofovir & $1(1,7)$ \\
Stavudin & $60(100)$ \\
Lamivudin & $53(88,3)$ \\
Zidovudin & $2(3,3)$ \\
Abacavir & $33(55,0)$ \\
Nevirapine & $22(36$ \\
Evafiren & $4(6,7)$ \\
Lopinavir/ritonavir (LPV/r) & \\
\hline
\end{tabular}

Bandung didapatkan 62 subjek, tetapi dua di antaranya terdapat kriteria eksklusi, yaitu didapatkan kelainan jantung bawaan, dan kelainan katup.

Tabel 2. Distribusi CD4 pada pasien anak HIV

\begin{tabular}{lc}
\hline Variabel & Nilai \\
\hline $\mathrm{CD} 4\left(\mathrm{sel} / \mathrm{mm}^{3}\right)$, rerata \pm SD & $822 \pm 380$ \\
$\mathrm{CD} 4$ Relatif $(\%)$ Median (min-maks) & $27,8(1,6-57,4)$ \\
\hline
\end{tabular}

Tabel 3. Distribusi dimensi ventrikel kiri

\begin{tabular}{lc}
\hline Variabel & Nilai \\
\hline IVSd (mm) & $7,25(3,9-10,3)$ \\
Median (min-maks) & \\
LVEDD (mm), & $39,20 \pm 4,88$ \\
rerata \pm SD & \\
PWd (mm) & $6,8(5,2-9,9)$ \\
Median (min-maks) & \\
LV mass (g) & $73,85(40,40-158,00)$ \\
Median (min-maks) & \\
LVMI (g/m2) & $76,45(48,90-156,00)$ \\
Median (min-maks)
\end{tabular}


Tabel 4. Korelasi nilai CD4 absolut dengan dimensi ventrikel kiri

\begin{tabular}{lccc}
\hline Korelasi & Koefisien korelasi & \multirow{2}{*}{$95 \%$ CI } & $\mathrm{p}$ \\
\cline { 2 - 2 } & $\mathrm{r}$ & & \\
\hline Nilai CD4 dengan LVMI & $-0,050$ & $-0,300-0,206$ & 0,377 \\
Nilai CD4 dengan LVM & $-0,341$ & $-0,547-(-0,096)$ & $0,004^{*}$ \\
\hline
\end{tabular}

Karakteristik dari subjek penelitian tertera pada Tabel 1. Sebanyak 53,2\% berjenis kelamin laki-laki dan $46,7 \%$ perempuan. Usia rata-rata subjek $10,8 \pm 3,5$ tahun, rata-usia saat terdiagnosis pertama kali 2,5 $(0,3-8,0)$ tahun dengan lama terapi ARV 7,5 $\pm 3,5$ tahun. Status gizi pada subjek, yaitu $68,3 \%$ status gizi normal, 13,3\% wasted, 11,7\% severe wasted, $5 \%$ overweight, dan $1,7 \%$ obesitas. Dua puluh lima (41\%) subjek ditemukan mengalami hipertrofi ventrikel kiri.

Seluruh subjek mendapatkan obat ARV kombinasi yang salah satunya terdiri atas lamivudine dan sisanya zidovudin/tenofovir/stavudin, dan nevirapin/efavirenz. Empat orang subjek menggunakan lopinavir/ritonavir, satu orang menggunakan kombinasi abacavir/efavirenz dan abacavir/tenofovir (Tabel 1).

Tabel 2 menunjukkan hasil pemeriksaan $\mathrm{CD} 4$, ratarata nilai $\mathrm{CD} 4$ absolut adalah $822 \pm 380 \mathrm{sel} / \mathrm{mm}^{3}$, dengan median CD4 relatif 27,8\%. Lima puluh (83,3\%) subjek tidak mengalami imunodefisiensi berdasarkan nilai CD4 absolut, $6(10 \%)$ subjek mengalami imunodefisiensi ringan, $4(6,7 \%)$ subjek mengalami imunodefisiensi berat menurut klasifikasi WHO.

Tabel 3 menunjukkan distribusi LVMI dan LVM tidak normal karena adanya nilai ekstrim pada beberapa subjek. Nilai median LVMI adalah 76,45 $\mathrm{gram} / \mathrm{m}^{2}$ sementara nilai median LVM 73,85 g. Subjek dengan LVMI di atas persentil 95 sebanyak 24 subjek. Nilai IVSd memiliki median 7,25 mm dan PWd 6,8 $\mathrm{mm}$. Left ventricular end diastolic diameter pada 60 pasien memiliki nilai rata-rata 39,20 4 , $88 \mathrm{~mm}$.

Tabel 4 menunjukkan analisis korelasi yang signifikan antara variabel LVM dengan variabel CD4 absolut $(\mathrm{r}=-0,347)$ yang menunjukkan tingkat korelasi yang lemah $(0,2<r<0,39)$. Pada analisis nilai CD4 dan LVMI didapatkan nilai $\mathrm{r}=-0,050$ yang menunjukan tidak ada korelasi yang signifikan $(\mathrm{p}=0,377)$.

\section{Pembahasan}

Keterlibatan kardiovaskular pada anak dengan infeksi HIV dapat dilihat dengan melakukan peme- riksaan ekokardiografi sejak awal sebagai dasar pemantauan keterlibatan kardiovaskular pada anak HIV. Pada beberapa analisis multivariabel, pemeriksaan ekokardiografi secara dini dengan melihat struktur dan fungsi jantung, seperti ketebalan dinding jantung dapat memberikan kontribusi signifikan secara statistik terhadap prediksi mortalitas.

Kami menemukan 25 (41\%) subjek yang mengalami hipertrofi ventrikel kiri, dengan LVMI di atas persentil 95, pada rata-rata usia $10,8 \pm 3,5$ tahun. $\frac{5}{}$ Hal ini menunjukkan bahwa terdapat peningkatan massa ventrikel kiri pada anak dengan infeksi HIV. Serupa dengan penelitian yang dilakukan oleh Okeke dkk di North Carolina pada subjek dewasa, 174 dari 473 subjek (34\%), mengalami hipertrofi ventrikel kiri berdasarkan kriteria LVMI menurut American Society of Echocardiography. Dua belas pasien (12\%) dilaporkan mengalami hipertrofi pada studi yang dilakukan pada studi anak di Afrika yang dinilai dengan LVMI. ${ }^{11}$. Barbaro dan Lipshutz juga melaporkan hal serupa ditemukan peningkatan massa ventrikel pada pasien anak yang terinfeksi HIV. $\underline{12}$

Status gizi dinilai berdasarkan IMT terhadap usia disesuaikan dengan memperhatikan nilai $Z$ score pada diagram WHO. Penelitian kami berbeda dengan penelitian Elizabeth dkk di Afrika. Elizabeth melaporkan bahwa anak dengan HIV positif memiliki status gizi yang secara signifikan lebih buruk dibandingkan dengan anak dengan HIV negatif. Pada penelitian kami 68,3\% mengalami status gizi baik. $\mathrm{Hal}$ tersebut dapat dihubungkan dengan tingginya CD4 atau tidak ditemukannya imunodefisiensi berdasarkan kriteria WHO pada subjek penelitian kami dengan rerata CD4 absolut.

Kami menghubungkan antara nilai CD4 absolut saat ini dengan LVMI, yaitu nilai massa ventrikel terhadap luas permukaan tubuh. Pengindeksan massa ventrikel kiri ini dapat memperhitungkan ukuran tubuh yang berbeda tanpa mengurangi efek kelebihan berat badan atau obesitas. Kami menemukan korelasi negatif pada hubungan antara nilai CD4 dengan indeks massa ventrikel kiri, tetapi tidak signifikan. 
Serupa dengan penelitian yang dilakukan oleh Mankwe dkk di Nigeria tidak menemukan hubungan yang signifikan antara CD4 dengan LVMI pada pasien dewasa. Beberapa penelitian sebelumnya telah mengevaluasi massa ventrikel kiri pada pasien yang terinfeksi HIV, tetapi mendapatkan hasil yang berlawanan. ${ }^{15}, \underline{16}$ Penelitian yang dilakukan oleh Ige $\mathrm{dkk}^{7}$ juga menggambarkan tingginya LVMI pada anak dengan HIV 66.5 (65.1-67.9) $\mathrm{g} / \mathrm{m}^{2}$ dibandingkan kelompok kontrol $56.9(55.5-57.3) \mathrm{g} / \mathrm{m}^{2}(\mathrm{p}=0.001)$. Cluster of differentiation 4 juga dapat menjadi faktor risiko independen peningkatan massa ventrikel kiri. Hal tersebut sesuai dengan penelitian yang dilakukan oleh Hsue dkk. ${ }^{17}$ Beberapa studi otopsi dan hewan percobaan mendapatkan hasil bahwa virus HIV secara langsung dapat memengaruhi sel-sel miokard dan dapat dikaitkan dengan pelepasan sitokin lokal serta faktor lain yang menyebabkan terjadinya inflamasi, miokarditis, dan kardiomiopati. $\frac{12,118}{}$ Kemungkinan lain dari peningkatan dan penurunan LVMI dapat dikaitkan dengan adanya infeksi oportunistik dan kejadian malnutrisi pada anak dengan HIV. ${ }^{15}$

Pada penelitian ini, kami hanya menganalisis dimensi jantung terhadap kondisi imunologis dari kasus HIV anak dan belum melihat fungsi secara keseluruhan sistem kardiovaskular yang mungkin lebih relevan untuk praktik klinis. Namun, penelitian ini dapat dijadikan titik awal dalam menganalisis perubahan mendasar dalam struktur jantung dan fungsinya sebelum terjadi masalah yang lebih berat.

Penelitian longitudinal diperlukan untuk memantau perkembangan dari massa ventrikel serta fungsi jantung kedepannya. Dengan demikian, perjalanan alami dari keterlibatan kardiovaskular pada anak dengan infeksi HIV dapat ditentukan, walaupun kami tidak menemukan adanya hubungan antara LVMI dengan nilai CD4 saat ini. Penelitian ini telah menunjukkan keterlibatan kardiovaskular pada anak HIV yang berobat di RS Hasan Sadikin Bandung. Untuk itu, skrining jantung dengan pemeriksaan ekokardiografi penting dilakukan untuk mengidentifikasi keterlibatan kardiovaskular pada pasien.

\section{Kesimpulan}

Abnormalitas kardiovaskular dapat terjadi pada anak infeksi HIV walaupun tidak menunjukkan adanya manifestasi klinis. Pada penelitian ini nilai CD4 tidak berhubungan dengan adanya peningkatan LVMI pada anak dengan HIV, tetapi ekokardiografi dapat menjadi teknik yang berguna untuk mendeteksi abnormalitas kardiovaskular pada anak HIV.

\section{Daftar pustaka}

1. Sliwa K, Carrington MJ, Becker A, Thienemann F, Ntsekhe M, Stewart S. Contribution of the Human immunodeficiency virus/acquired immunodeficiency syndrome epidemic to de novo presentations of heart disease in the heart of Soweto Study cohort. Eur Heart J 2011;13:866-74.

2. Kementerian Kesehatan Republik Indonesia. Pedoman penerapan terapi HIV pada anak. Jakarta: Kemkes RI; 2014.

3. Shoko C, Chikobvu. A superiority of viral load over CD4 cell count when predicting mortality in HIV patients on theraphy. BMC Infect Dis 2019;19:169.

4. Direktorat Jenderal P2P, Kementerian Kesehatan Republik Indonesia. Laporan perkembangan HIV AIDS \& lnfeksi menular seksual (IMS) triwulan IV tahun 2018. Jakarta: Kemenkes RI;2019.

5. Khoury P, Misnefes M, Daniels SR, Kimball T. Age-specific reference intervals for indexed left ventricular mass in children. J Am Soc Echocardiogr 2009;22:709-14.

6. Singh P, Hemal A, Agarwal S. Cardiac manifestation in HIV infected children. Indian J Pediatr.2015:82:230-4.

7. Ige O, Oguche Stepen, Yildwan Christoper. Left ventricular mass and dastolic dysfunction in children infected with the human immunodeficiency virus. Nig J Cardiol 2018;11:7-12.

8. Devereux R, Roman M. Left ventricular hypertrophy in hypertensive: stimuli, patterns, and consequences. Hypertens Res 1999;22:1-9.

9. Lang R, Michelle Bierig, Richard B D, dkk. Recommendation for chamber quantification J Am Soc Echocardiogr 2005;18:1454-7.

10. Okeke L, Alanezi F, Bloomfield G, dkk. Determinants of left ventricular hypertrophy and diastolic dysfunction un an HIV clinical cohort. J Card Fail 2018;24:496-503.

11. Chelo D, Wawo E, Sisha W, Anakeu A, dkkl. Cardiac Anomaly in a group of HIV-infected children in a pediatric hospital; an echocardiography study in Yaounde. Cardiovaskuler Diagn Ther 2015;5:444-53.

12. Barbaro G, Barbarini G, Di Lorenzo G. Early impairment of systolic and diastolic function in asymptomatic HIVpositive patients: A multicenter echocardiographic and echoDoppler study. AIDS Res Hum Retroviruses. AIDS Res Hum Retroviruses 1996;12:1559-63.

13. Elizabeth K, Shane A Norris, John M Pettifor, dkk. NUtritional 
status and HIV in rural South African children. BMC Pediatric 2011;11:2-13.

14. Mankwe AC, Odia James. Association between CD4+ lymphocyte count and left ventricular diastolic function and geometry in newly diagnosed highly active antiretroviral therapy (HAART) Naive HIV/AIDS patients seen at University of Port Harcourt Teaching Hospital, Port Harcourt, Rivers State, Nigeria. J Cardiovasc Dis Diag 2017;5:1-10.

15. Samaan SA, Raizada V, Schade DS, Koster F. Myocardial athrophy in acquired immunodeficiency syndrome-associated wasting. Am Heart J 1995;130:823-7.
16. Lipshultz SE OE, Sanders SP, Colan SD. Immunoglobulins and LV structure and function in pediatric HIV infection. Circulation 1995;92:2220-5.

17. Hsue P, Lo JC, Franklin A, Bolger AF, Martin JN, Deeks SG, $\mathrm{dkk}$. Progression of atherosclerosis as assesed by carotid intimamedia thickness in patient with HIV infectiom. Circulation 2004;1:1603-8.

18. Barbaro G, Di Lorenzo G, Grisorio B, dan Barbarini G. Incidence of dilated cardiomyopathy and detection of HIV in myocardial cells of HIV-positive patients. N Engl J Med 1998;339:1093-9. 